\title{
The U.S. Consumption Boom and Trade Deficit
}

\section{Yi Wen and Luke M. Shimek}

$\mathrm{T}$ he U.S. trade deficit has increased more or less continuously since the early 1980s. The blue line in panel A shows that the trade deficit was essentially zero during the 1960s and 1970s, but started to take a dramatically different path in 1982, accelerating from less than $\$ 20$ billion (0.6 percent of GDP) to an immense $\$ 762$ billion (5.8 percent of GDP) in 2006. A trade deficit of 5 percent of GDP is usually found in emerging-market economies, where capital goods make up a large share of imports. In contrast, an increase in imports of consumer goods accounts for the bulk of the U.S. trade deficit.

Exports and imports as shares of GDP gradually increased at roughly the same pace from the 1960s until the early 1980s, reflecting increases in the openness of the U.S. economy. How ever, since the early 1980s, the increase in the imports-to-GDP ratio outpaced the increase in the exports-to-GDP ratio. Again, it has been an increase in imported consumer goods leading the way.

Meanwhile, as the black line in panel B shows, the pattern of household consumption as a share of personal income has been similar to the pattern of the trade deficit since the early 1980s. Consumption as a share of personal income was essentially constant in the 1970s. In the early 1980s, though, it began a dramatic upward trend; as a result, the national saving rate started to decline, falling from 10 percent in 1980 to 0.4 per- cent in 2006 (the black line in panel A). Household's consumption share of disposable income also increased, from 87.5 percent in 1980 to 95.8 percent in 2006, which implies an additional $\$ 802.5$ billion of personal income was consumed rather than saved.

This consumption boom and the associated decline in the saving rate coincided with a large increase in revolving credit outstanding, which consists primarily of household credit card debt. The blue line in panel B shows a pattern of significant growth in the expansion of revolving credit in the early 1980s: It increased from about $\$ 54.8$ billion (2.7 percent of personal income) in 1980 to about $\$ 854.6$ billion today (8.9 percent of personal income).

It is striking to see how closely these numbers match: the increase in the trade deficit ( $\$ 762$ billion), the increase in consumption due to a rise in consumption's share of personal income ( $\$ 802$ billion), and the increase in revolving credit outstanding (about $\$ 800$ billion). Time will tell whether these close matches are purely accidental or reflect deeper causal relationships.

Johnson, Kathleen W. "Recent Developments in the Credit Card Market and the Financial Obligations Ratio." Federal Reserve Bulletin, Autumn 2005, pp. 473-86.

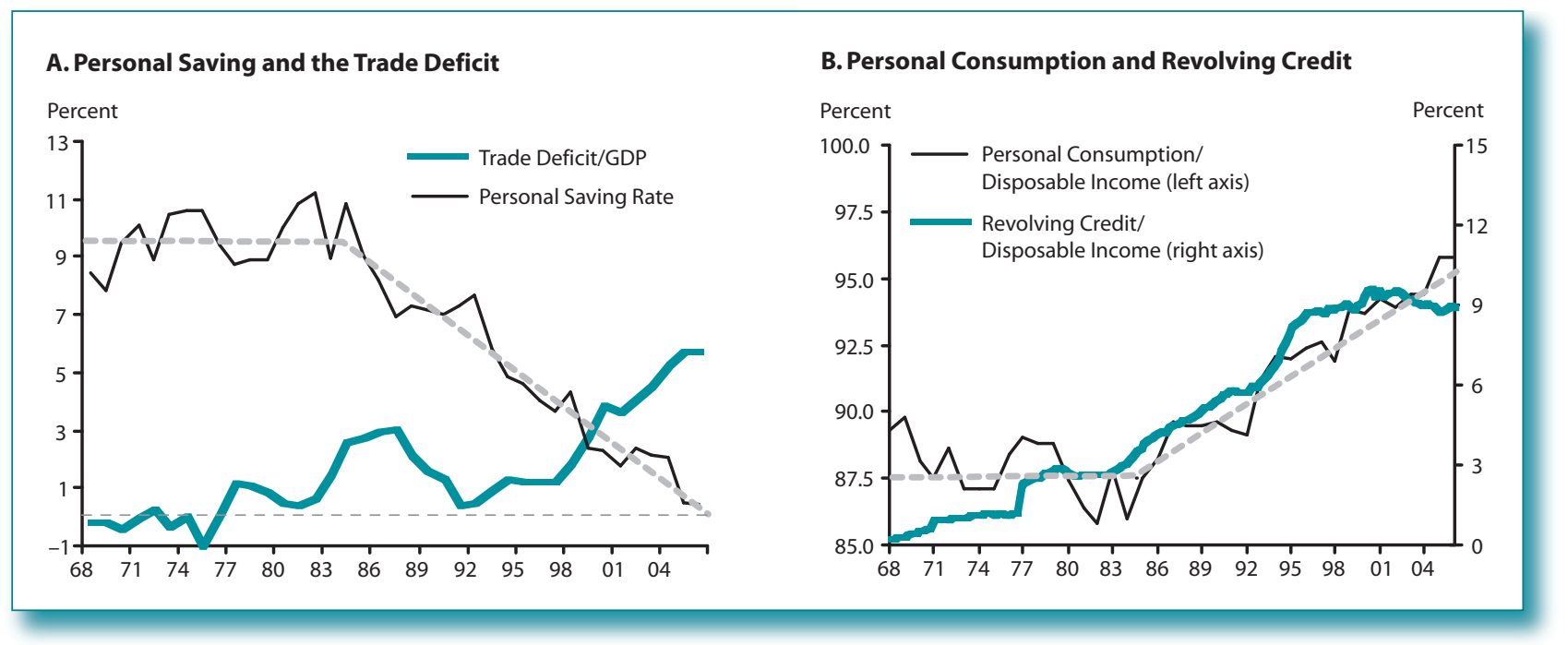

Views expressed do not necessarily reflect official positions of the Federal Reserve System. 